\title{
A Risk-Based Multi-Criteria Decision Analysis Approach to Evaluating Transboundary Water Development-The Case of Lower Mekong River Basin
}

\author{
Nguyen Phuong Lan \\ Graduate School of Global Environmental Studies, Kyoto University, Kyoto, Japan \\ Email: nguyen.phuong.83s@st.kyoto-u.ac.jp
}

How to cite this paper: Lan, N.P, (2021) A Risk-Based Multi-Criteria Decision Analysis Approach to Evaluating Transboundary Water Development-The Case of Lower Mekong River Basin. Journal of Environmental Protection, 12, 345-370.

https://doi.org/10.4236/jep.2021.125022

Received: April 2, 2021

Accepted: May 24, 2021

Published: May 27, 2021

Copyright ( 2021 by author(s) and Scientific Research Publishing Inc. This work is licensed under the Creative Commons Attribution International License (CC BY 4.0).

http://creativecommons.org/licenses/by/4.0/ (c) (i) Open Access

\begin{abstract}
The Lower Mekong River basin (LMB) covers the lower part of the Mekong river basin, including Laos, Thailand, Cambodia and Vietnam. Due to numerous pressures from high population growth and intensive hydropower development, the LMB has been facing significant challenges concerning its biodiversity and ecosystem. In 2017, Mekong River Commission (MRC), an intergovernmental organisation founded in 1995 among LMB countries, established the Council Study, which analysed the impacts of water development scenarios concerning the environmental, socioeconomic aspects of the LMB. This paper explores the nature of risks to the LMB water development and subsequently evaluates LMB's water development scenarios described in the Council Study by using a multi-criteria decision analysis (MCDA) method. MCDA method has been widely applied in the field of water resource management in order to assist the decision-making process by systematically evaluating a certain number of alternatives against well-selected criteria through a preference rating scheme. By implementing a risk-based comprehensive assessment of the LMB transboundary water, this study provides insights into the impacts of the increasing risks to the ecosystem and human beings on the water development of the basin over time, which assists to change the awareness and the perspective toward humans' risks and transboundary river ecosystem of decision-makers. This paper provides valuable recommendations for MRC to improve their policy concerning benefit-sharing scheme, water planning and risk mitigation strategies.
\end{abstract}

\section{Keywords}

Lower Mekong Basin, Multi-Criteria Decision Analysis, 


\section{Introduction}

There are around 280 international river basins worldwide which contribute to approximately 60 percent of global water flows and accommodate nearly two-fifth of the world's inhabitants [1] [2]. The transboundary river systems, which might be shared among several countries with high socio-economic and environmental interdependencies, strongly support people's lives and the global biodiversity [3]. Given the vital role of shared river basins and the differences of riparian countries' interest concerning their development priorities, managing these water resources in the context of environmental and social rapid changes is an enormous challenge. These problems are expected to become more severe over time, resulting from the increasing risk and uncertainty linked with population growth, climate change and other water-related evolution [4] [5]. Therefore, it is crucial for decision-makers in shared river basins to understand the nature of risk to the basin development to implement risk-based evaluation and then take essential steps to integrate these assessments into their water planning process.

The decision-making process related to water use and distribution often draws much attention to economic and political rather than social concerns [4]. When people cannot use water sustainably and equitably, the exploited ecosystem and humans dependent on them will be first and foremost affected seriously [6]. According to UN World Water Development Report, freshwater ecosystems face enormous negative impacts from direct sources, such as water quality degradation, and indirect sources arising from socio-economic changes [6] [7]. Hence, the ecosystem approach might be considered a promising approach to support the sustainability and integration of water management [8]. Decision-makers must also better understand and gradually change their perspectives toward humans' risks and transboundary river ecosystem. Additionally, risk-based comprehensive assessment of transboundary water development is essential, not only for providing insights into the impacts of risks on the final evaluation but also for supporting decision-making, planning and management processes in the long term.

The Mekong river, one of significant international freshwater, rises in China and then runs across other five countries before joining the South China Sea. The Lower Mekong River basin (LMB), which provides homes and livelihoods for approximately 65 million people, covers the lower part of the Mekong river basin (MRB) within the territories of four countries, including Laos, Thailand, Cambodia and Vietnam [9]. Due to numerous pressures ranging from high population growth to industrial and agricultural development, the Mekong river has been facing significant challenges concerning its biodiversity and ecosystem 
condition for the past 30 years [10]. Additionally, the river's massive hydrological changes are likely to give negative impacts on the basin's ecosystem and leave many people vulnerable to the impacts [11]. As a result of the rapid development of the basin's water resources over the past decades, the basin's ecosystem and communities are under high pressures, which lead to the growing demand for a comprehensive assessment of water development based on these pressures (Figure 1).

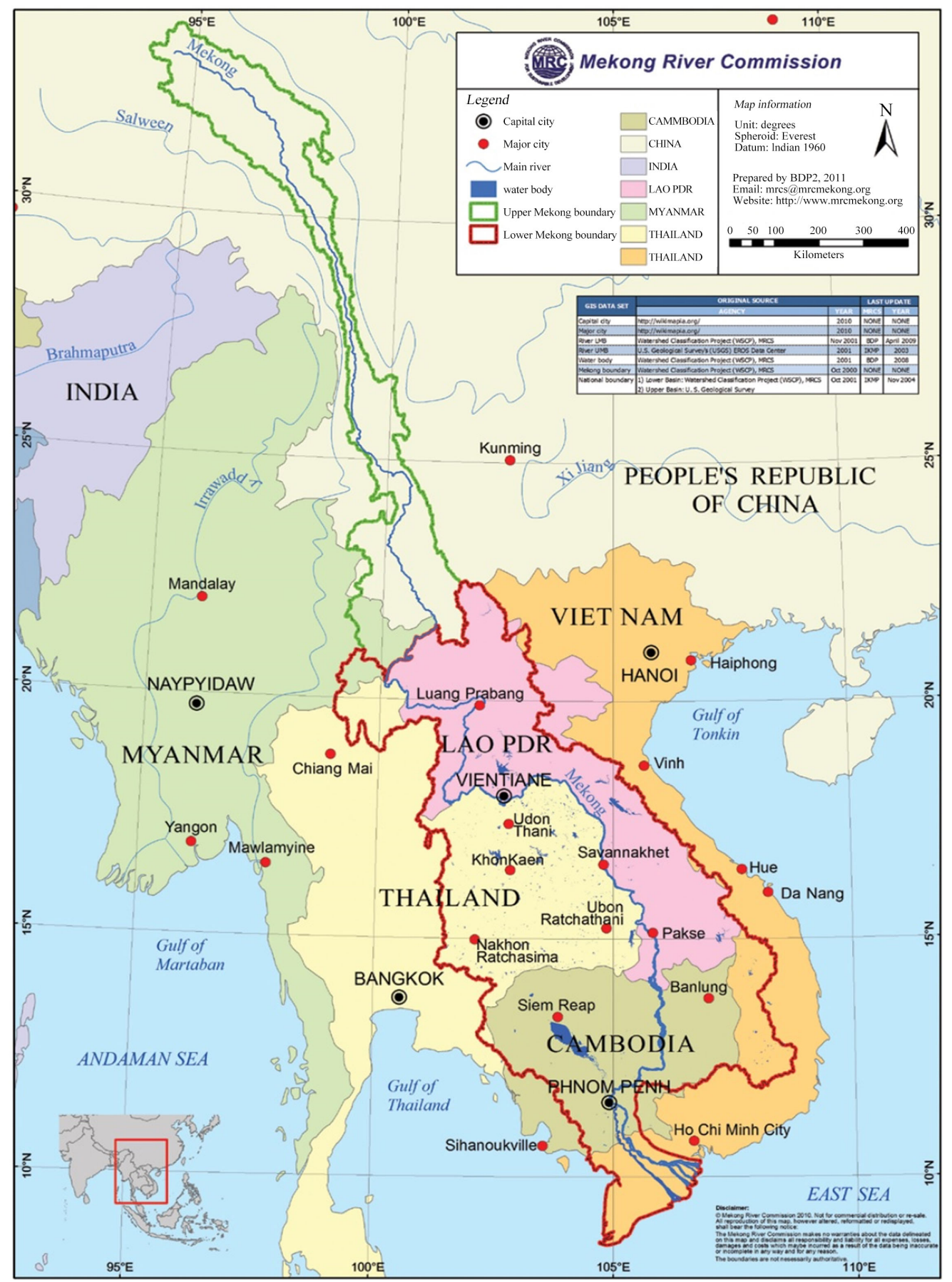

Figure 1. Map of the Mekong river basin [12]. 
There have been constant efforts by Mekong River Commission (MRC), an intergovernmental organisation founded in 1995 for the comprehensive cooperation between four Lower Mekong countries, to identify and evaluate the risks associated with the LMB development. These risks, also occasionally replaced by the term "challenges" or "impacts" in the MRC documents, were similarly addressed in the State of the Basin Report in 2003, 2010 and 2018, focusing on risks of floods and droughts and growing population as well as threats to water quality, ecosystem, public health and human welfare [9] [13] [14]. Notably, in 2018, MRC has identified key challenges with their alarming rates, by which the level of concerns about these challenges was addressed [9]. The risks discussed in many MRC reports provide an overview of existing and potential risks without exactly pointing out the risk level, and more importantly, comparing the Mekong's situation with other river basins' to stress the need for taking these risks into account during the planning process of the MRC. An adequate knowledge of the Mekong's risk profile under which risks to the Mekong water development are analysed and recognised as drivers of change is necessary.

To study the comprehensive development scenarios of the LMB, MRC has published some in-depth reports from 2010 to 2018, including the Assessment of Basin-wide Development Scenarios, Strategic Environmental Assessment of Hydropower on the Mekong Mainstream and The Study on Sustainable Management and Development of the Mekong River including Impacts of Mainstream Hydropower Projects (the Council Study). While the Strategic Environmental Assessment mainly concentrated on analysing the impacts of mainstream hydropower development strategies, the Assessment of Basin-wide Development Scenarios and the Council Study had a broader target to all water-related development to assess the environmental, economic and social cumulative impacts of each scenario [15] [16] [17]. The Council Study, a complete version of the Strategic Environmental Assessment, covers many of the LMB's future development scenarios with cross-sectoral and integrated assessments and aims to support the sustainable development of the LMB, which was not addressed in the Strategic Environmental Assessment. Although MRC systematically analysed the impacts of water development scenarios concerning the environmental, social and economic aspects were in the Council Study, this organisation has yet to carry out a complete evaluation and ranking of main scenarios against all water-related issues, particularly risk-related issues.

A study evaluating the water development scenarios in the context of transboundary river basin can identify the existing and future impacts of water-related issues on the basin's long-term development. The literature has been focused solely on modelling the water development scenario [18], analysing basin's hydro political tensions [19] or generally assessing the basin's water policy [20], while less concentrated on carrying out a risk-based evaluation as in the LMB case. Also, previous studies have mainly analysed the water allocation and basin development scenarios regarding local river basins rather than water de- 
velopment scenarios of international river basins [21] [22]. Moreover, few studies focus on risk-based scenario assessment in shared water bodies, such as in the LMB, which might provide a new approach to assess the basin water resources and accordingly support the basin's water resource management.

The literature on water management in the LMB has focused on analysing the diverse impacts of hydropower development and climate change on the environmental and socio-economic development of the LMB [23] [24] [25] [26]. By comparing the results of the Assessment of Basin-wide Development Scenarios with their assessment results, Intralawan et al. (2018) concluded that it is difficult to consider the priority between hydropower development and biodiversity sustainability, and identify other social and ecological impacts [27]. The study also suggested that the LMB policy-makers should consider the balance of water-food-energy nexus for the basin's sustainable development. T. Piman et al. (2013) identified hydrological changes under each scenario in the Assessment of Basin-wide Development Scenarios and then highlighted the importance of ecological and climate change uncertainties to the LMB's water planning process [28]. These studies are essential to understand the existing and potential risks to the long-term development of the basin, which will support the water scenario evaluation process. However, they have not evaluated and ranked the basin development scenarios using the generated impacts. Particularly, there is no study utilising the scenarios described in the MRC Council Study to implement the water development evaluation.

Given the reasons above, this paper explores the nature of risks to the MRB water development and subsequently evaluates LMB's water development scenarios to answer the following research questions: 1) What are the characteristics of the risks to the transboundary river's ecosystem and human beings, and 2) How do river basin's risk levels affect the evaluation of transboundary water development scenarios.

This paper is organised as follows. The following section presents the literature relating to the water resource management of the LMB and previous studies on transboundary water resource evaluation. The research methodology, research design and data collection process are accordingly introduced. Then, the research results are presented, and the findings are discussed, identifying the key issues that MRC and all LMB countries should take into account during their water planning and evaluating process. The last sections involve conclusions with policy implications and recommendations for future water resource management and cooperation in the LMB.

\section{Theoretical Framework}

Water resource management is a complex and interdisciplinary issue, which involves multi-sectoral areas [29]. In water management, decision-makers face enormous challenges in making the final selection since the decision-making process is characterised by multiple conflicting objectives, including economic, 
social and environmental issues [30]. Due to the complexity of transboundary river, many significant factors need to be considered when carrying out an assessment of transboundary water development. Therefore, along with the increasing awareness of shared water bodies' vital role, many researchers have generated interest in employing a multi-criteria decision analysis (MCDA) approach to support the decision-making process relating to transboundary water planning and managing.

MCDA, a widely used method to assist evaluation and management decisionmaking issues, is primarily concerned with situations in which decision-makers systematically evaluate a certain number of alternatives against well-selected criteria through a preference rating scheme [31] [32] [33]. MCDA is both an approach and a compilation of steps aiming at providing an aggregate ranking of alternatives, from the most favored to the least preferred one. The detailed steps of a MCDA model include: 1) Identify the decision objectives and the alternatives; 2) Identify the criteria for assessing the alternatives; 3) Score the criteria weights which reflect the relative importance of each criterion to the decision-making process; 4) Calculate the overall weights of alternatives against the criteria; 5) Rank the alternatives and make the final decision. There are two quantified steps which should be noted when applying MCDA assessment. First, the relative weights of criteria are calculated using normalization technique (Table 1).

Second, the overall preference score of each alternative is equal to the weighted average of its score across all criteria, which can be calculated by the following formula:

$$
S_{i}=w_{1} s_{i 1}+w_{2} s_{i 2}+\ldots+w_{n} s_{i n}=\sum_{j=1}^{n} w_{j} s_{i j},
$$

where: $s_{i j}$ is the preference score of the $I^{\text {th }}$ alternative on the $f^{\text {th }}$ criterion,

$w_{j}$ is the weight of the $f^{\text {th }}$ criterion,

$S_{i}$ is the overall preference score of the $I^{\text {th }}$ alternative.

Over the past decades, a large body of literature has applied MCDA in the field of water resource management and planning ([35] [36] [37]. Besides, the MCDA model has been applied in many other water-related sectors, such as groundwater management [38] [39]; water supply [40] [41] and water governance [42] [43].

Concerning characteristics of criteria used in the MCDA model concerning water resource management, Zolghadr-Asli et al. (2021) identified a range of MCDA evaluation criteria, including economic, social, environmental, technical, legislative and political criteria [33]. More importantly, most of the previous studies prefer cost-and-benefit-based, monetary-based or technical-based criteria for their evaluation model, while there is a notable shortage of studies employing risk-based criteria. Regarding the risk-based evaluation MCDA model, a small number of previous studies has examined the different water supply strategies under uncertainty of negative demand and population growth or environmental-related issues [44] [45]. 
Table 1. Normalization techniques (adopted from [34]).

\begin{tabular}{|c|c|c|}
\hline Normalization technique & Condition of use & Formula \\
\hline \multirow[t]{2}{*}{ Linear sum-based } & Cost criteria & $n_{i j}=\frac{1 / r_{i j}}{\sum_{i=1}^{m} 1 / r_{i j}}$ \\
\hline & Benefit criteria & $n_{i j}=\frac{r_{i j}}{\sum_{i=1}^{m} r_{i j}}$ \\
\hline \multirow[t]{2}{*}{ Linear Max } & Cost criteria & $n_{i j}=1-\frac{r_{i j}}{r_{\max }}$ \\
\hline & Benefit criteria & $n_{i j}=\frac{r_{i j}}{r_{\max }}$ \\
\hline \multirow[t]{2}{*}{ Linear Max-Min } & Cost criteria & $n_{i j}=\frac{r_{\max }-r_{i j}}{r_{\max }-r_{\min }}$ \\
\hline & Benefit criteria & $n_{i j}=\frac{r_{i j}-r_{\min }}{r_{\max }-r_{\min }}$ \\
\hline
\end{tabular}

There is a growing trend in using the MCDA method to evaluate water management alternatives concerning local/national river basin issues [30] [46] [47] [48] rather than at international river basin issues. The past research has primarily applied the MCDA model to analyse water governance and water policy of international water organisations [20] [49]. Previous studies have yet to explore the possibility of utilising risk-based criteria in the MCDA model to assess water development scenarios in the transboundary river basin.

\section{Data and Methods}

\subsection{Data Collection}

The data extracted from the river basins assessment of Transboundary Water Assessment Program (TWAP), a research component of a program initiated by the Global Environmental Facility, were used to conduct a comparative analysis of the relative risk of the MRB and the other river basins worldwide. TWAP was developed by the United Nations Environment Program (UNEP) to provide a baseline assessment of the relative risk to ecosystems and the environment of global transboundary water resources. UNEP and its partners expected the assessment results to identify river basins at risk and raise awareness of transboundary waters' vital role.

Based on a set of indicators classified into five main indicators and fifteen sub-indicators (Table 2), the TWAP assessment presents the assessment results and background information of 286 transboundary river basins at the basin and basin country unit level. The risk levels by indicators of each river basin were finally analysed by adopting five categories from "very low" to "very high" with the corresponding points from 1 to 5 . 
Table 2. TWAP River basins assessment indicators (including baseline indicators for 2010 and projected indicators for 2030 and 2050) [50].

\begin{tabular}{|c|c|c|}
\hline \multirow{2}{*}{ Main indicators } & \multicolumn{2}{|l|}{ Sub-indicators } \\
\hline & Baseline (2010) & Projected (2030/2050) \\
\hline \multirow[t]{3}{*}{ 1. Water quantity } & 1. Environmental water stress & 1. Environmental water stress \\
\hline & 2. Human water stress & 2. Human water stress \\
\hline & 3. Agricultural water stress & \\
\hline \multirow[t]{2}{*}{ 2. Water quality } & 4. Nutrient pollution & 4. Nutrient pollution \\
\hline & 5. Wastewater pollution & \\
\hline \multirow[t]{4}{*}{ 3. Ecosystems } & 6. Wetland dis-connectivity & \\
\hline & 7. Ecosystem impacts from dams & \\
\hline & 8. Threat to fish & \\
\hline & 9. Extinction risk & \\
\hline \multirow[t]{3}{*}{ 4. Governance } & 10. Legal framework & \\
\hline & 11. Hydro-political tension & 11. Hydro-political tension \\
\hline & 12. Enabling environment & \\
\hline \multirow[t]{3}{*}{ 5. Socioeconomics } & $\begin{array}{l}\text { 13. Economic dependence on water } \\
\text { resources }\end{array}$ & 13. Change in population density \\
\hline & 14. Societal wellbeing & \\
\hline & 15. Exposure to flood and drought & \\
\hline
\end{tabular}

The evaluation of water development scenarios regarding environmental and ecosystem risks of the LMB was presented using data collected from the MRC Council Study. The study is a six-year study conducted by the MRC member countries from 2012 to 2017 with projections to 2040, focusing on analysing the impacts of water development on sustainable development of the LMB, especially the impacts on the environment and human beings. The Council Study covered the critical water resources management sectors that contribute to the LMB development, including hydropower, agriculture and irrigation, flood protection, navigation, fisheries and water use. These topics were thoroughly investigated and estimated for different development scenarios from the baseline scenario in 2007 to the future scenario in 2040.

\subsection{Methods}

First, a comparative analysis approach is used to construct a complete risk profile of the MRB. Rather than solely describing a picture of the MRB's current risk level, this study compares the MRB's risk profile and the other global river basins' risk profile to highlight the significant differences in the level of threats and reveal the future changes in risk level. The next stage is to establish an MCDA model to evaluate the water development scenarios of the LMB (Figure 2). 


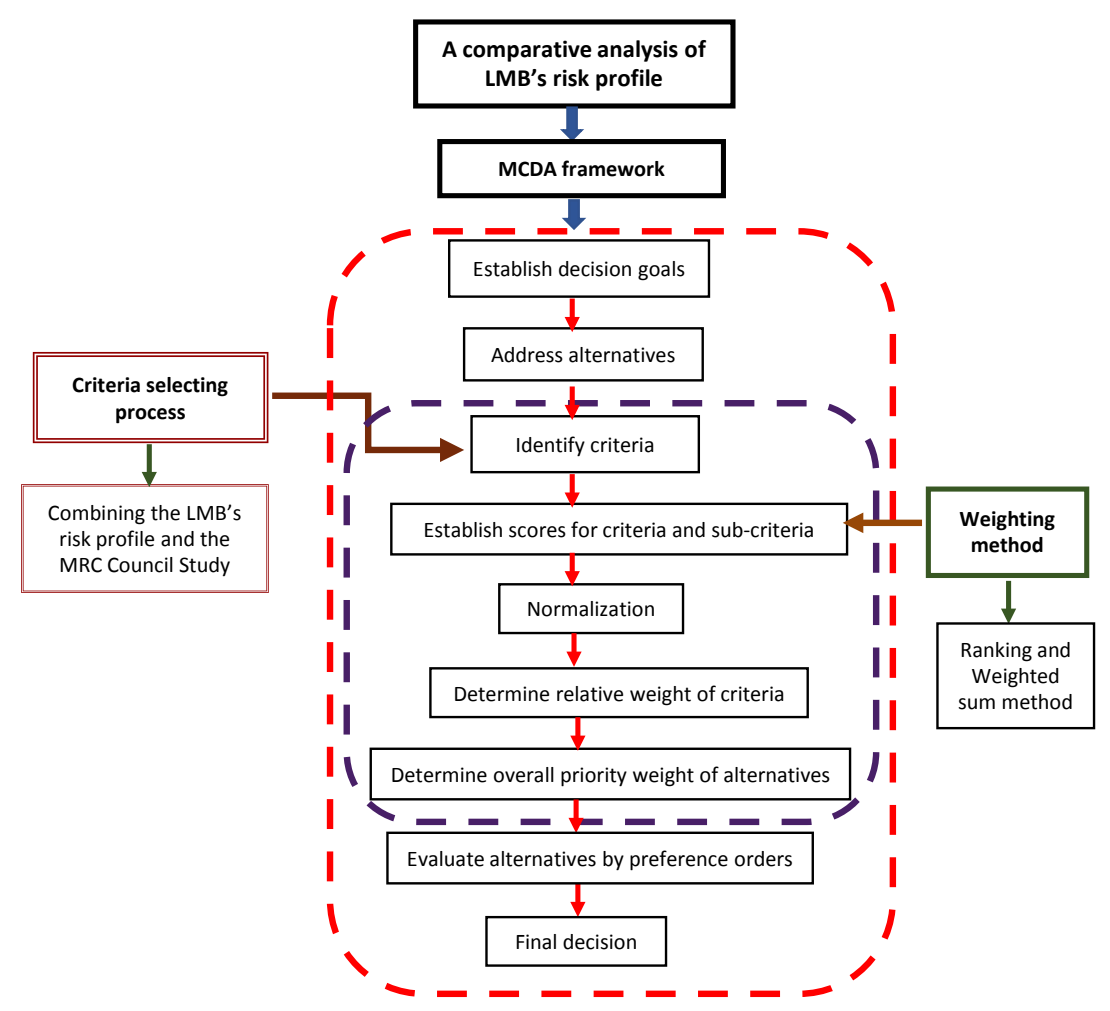

Figure 2. Research framework for evaluating the water development scenarios in the LMB.

MCDA is an organized and transparent approach to problem solving that improves objectivity and produces trusted outcomes with a reasonable satisfaction level [51]. The application of MCDA method has been rapidly increasing due to the fact that the decision-making process relating to urgent real-life problems requires the consideration of multiple criteria [52]. In addition, this approach is distinguished by its ability to improve the decision's quality as well as to handle a variety of conflicting objectives with different perspectives of many stake-holders involving in the policy-making process [53].

A complete MCDA model for the LMB case is established as follows:

- Setting the ultimate goal and identifying the alternatives

This MCDA model aims to evaluate the LMB's water development scenarios regarding the risks to the environment, ecosystems and human beings and the alternatives are the water resource development scenarios taken from the MRC Council Study. The MRC study covers three main water resource development scenarios and dozens of sub-scenarios during 20 years from 2020 to 2040. Each scenario considered the change over time of water resources and hydropower development estimated for the LMB. This study focuses on three main development scenarios:

- Scenario M1: the 2007 baseline development scenario.

- Scenario M2: the 2020 definite future development scenario.

- Scenario M3: the 2040 planned development scenario.

The author then evaluated the performance of these three main development 
scenarios concerning the assessment criteria, which are categorised in the next step.

- Selecting the criteria for assessment

A set of assessment criteria is carefully selected considering the characteristics of the LMB's risk profile and the MRC Council Study's data availability. The criteria presented in this study address the most intense pressures on the sustainable development of the environment, ecosystem and livelihoods of the LMB (Table 3).

Additionally, because the TWAP indicators were constructed applicable to any of the 286 river basins, it was challenging and impractical to incorporate the complete set of TWAP indicators into the LMB case's MCDA model. Finally, the author took a total of four main criteria and nine sub-criteria used in the MCDA model from a set of five main indicators and fifteen sub-indicators of the TWAP river basins assessment (Table 4).

- Determining the criteria weights

In a basic MCDA model, the decision-makers involved in weighing criteria are selected based on their expertise, academic knowledge and practical experiences. The decision-makers then assign criteria weights after considering their preferences. However, this decision-making process has some drawbacks because the decision-makers often hold different perceptions of the same problem, making it difficult to reach the final decision on the relative weights of criteria. More importantly, inconsistency problems are likely to occur when making decisions subjectively. To avoid these difficulties, the author employs the objective instead of the subjective weighting process. The scores for main and sub-criterion were assigned using the MRB risk values. The relative weights of the main criteria are then obtained by taking the average of their respective sub-criteria risk values while those of the sub-criteria are equal to their risk values.

Table 3. Major risks to the development of the MRB [9].

\begin{tabular}{|c|c|c|c|}
\hline $\begin{array}{l}\text { Basin risk-related } \\
\text { issues }\end{array}$ & Risk sources & Level & References \\
\hline Water quality & Conditions of water quality & 2 & State of the basin report 2018 \\
\hline \multirow{2}{*}{ Water quantity } & $\begin{array}{l}\text { Increasing water uses in the future } \\
\text { concerning water resource } \\
\text { development and climate change. }\end{array}$ & 1 & $\begin{array}{l}\text { Basin Development Strategy for } \\
\text { the MRB 2021-2030, State of the } \\
\text { basin report } 2018\end{array}$ \\
\hline & $\begin{array}{l}\text { Conditions of water flow in } \\
\text { mainstreams (water uses for various } \\
\text { sectors) }\end{array}$ & 1 & $\begin{array}{l}\text { Basin Development Strategy for } \\
\text { the MRB 2021-2030, State of the } \\
\text { basin report } 2018\end{array}$ \\
\hline \multirow{2}{*}{$\begin{array}{l}\text { Environment/ } \\
\text { Ecosystem }\end{array}$} & $\begin{array}{l}\text { Heavy fishing pressure and fish } \\
\text { populations }\end{array}$ & 2 & $\begin{array}{l}\text { Basin Development Strategy for } \\
\text { the MRB 2021-2030, State of the } \\
\text { basin report } 2018\end{array}$ \\
\hline & $\begin{array}{l}\text { Critical loss of remaining wetland, } \\
\text { reducing ecosystem services }\end{array}$ & 2 & $\begin{array}{l}\text { Basin Development Strategy for } \\
\text { the MRB 2021-2030 }\end{array}$ \\
\hline \multirow[t]{2}{*}{ Socioeconomics } & $\begin{array}{l}\text { More severe floods and droughts due } \\
\text { to climate change }\end{array}$ & 1 & $\begin{array}{l}\text { Basin Development Strategy for } \\
\text { the MRB 2021-2030 }\end{array}$ \\
\hline & Living conditions and wellbeing & 1 & State of the basin report 2018 \\
\hline
\end{tabular}

Note. Level 1: Some significant concerns to address; Level 2: Considerable problem, urgent actions needed. 
Table 4. Assessment criteria of MCDA model.

\begin{tabular}{|c|c|c|}
\hline Main criteria & Sub-criteria & Description \\
\hline \multirow[t]{2}{*}{$\mathrm{C} 1$-Water quantity } & C1.1-Human water stress & $\begin{array}{l}\text { Estimations of domestic water } \\
\text { consumption in litres per capita } \\
\text { per day }(1 / c / d)\end{array}$ \\
\hline & C1.2-Agricultural water stress & $\begin{array}{l}\text { Total annual irrigation water demand } \\
{\left[\mathrm{m}^{3} / \mathrm{s}\right] \text { by country and main scenario }}\end{array}$ \\
\hline C2-Water quality & C2.1-Nutrient pollution & $\begin{array}{l}\text { Average total Nitrogen and Phosphorus } \\
\text { exceeded the US EPA water quality } \\
\text { standard. }\end{array}$ \\
\hline C3-Ecosystems & $\begin{array}{l}\text { C3.1-Ecosystem impacts from } \\
\text { dams }\end{array}$ & $\begin{array}{l}\text { Dam density (the density of tributary and } \\
\text { mainstream dams) }\end{array}$ \\
\hline \multirow{3}{*}{ C4-Socioeconomics } & C3.2-Threat to fish & $\begin{array}{l}\text { Percentage of mean predicted } \\
\text { change of non-native fish in river } \\
\text { sections. }\end{array}$ \\
\hline & $\begin{array}{l}\text { C4.1-Economic dependence on } \\
\text { water resources }\end{array}$ & $\begin{array}{l}\text { Monthly irrigation water diversion } \\
\text { by country in each main scenario }\end{array}$ \\
\hline & C4.2-Societal wellbeing & $\begin{array}{l}\text { Poverty levels (\% of people below the } \\
\text { poverty line) of corridor zones by } \\
\text { development scenario }\end{array}$ \\
\hline
\end{tabular}

Next, numerical data for each criterion were calculated for three main scenarios on the basin and basin country scales. A normalisation technique is utilised to transform these values into different units to comparable output vectors where all elements sum up to 1 . Concerning to the nature of the selected criteria that reflect the risks to ecosystems and the environment, this study portrays them as cost criteria and uses a linear sum-based method for normalisation, as shown in the following equation:

$$
n_{i j}=\frac{1 / r_{i j}}{\sum_{i=1}^{m} 1 / r_{i j}},
$$

where: $r_{i j}$ is the numerical data of the $f^{\text {th }}$ criteria of scenario,

$n_{i j}$ is the normalised value of $f^{\text {th }}$ criteria of scenario $i(n=\overline{0.1})$.

Accordingly, the relative weights calculated previously were normalised to produce the main criteria' final weights and the sub-criteria local weights. Next, the sub-criteria final weights are calculated by multiplying their local weights by the final weights of their respective main criteria.

- Weighting the alternatives (scenarios) and making a final evaluation

A final scenario evaluation was carried out to rank the alternatives against all the criteria. First, the performance of each scenario for each criterion was assessed, in which the more critical the scenario was, the higher the score that the scenario could receive. Consequently, the aggregate weight score of a scenario was finalised by adding its scores across the criteria. Each criterion's contribution to the scenarios' final ranking and the final ranking of each scenario are clearly presented. 


\section{Results}

\subsection{A Comparative Analysis of the MRB Risk Profile}

\subsubsection{A Comparison between the MRB and the Other Basins Worldwide}

According to the TWAP intensive assessment, the relative risks related to a wide range of sustainable development issues were analysed for 286 global transboundary rivers, including the MRB, to identify river basins with significant problems and high potential risks. The risk points by criteria were calculated from basin to basin, and the detailed risk points of member countries of each river basin were also obtained. By sequentially calculating and comparing the global average risk points with the MBR's risk points, the typical variation of risk points across criteria is revealed, and that portrays the fundamental differences between the MRB and global trend.

As shown in Figure 3, the threats to the MRB are generally higher than those at the global average scale across fifteen sub-criteria, especially regarding exposure to floods and droughts, economic dependence on water resources, and threat to fish. While the global average risk points are ranging from the lowest of 1.95 for the "environmental water stress" criteria to the highest of approximately 4.0 for the "wastewater pollution" criteria, the findings show that the risk points of the MRB reach a peak of 5.0, which is 2.5 times higher than its lowest level. Of all the criteria, wastewater pollution has become one of the biggest challenges facing both the MRB and river basins worldwide. More importantly, compared to the heavy dependence of economic development on water resources, it might be a worrying matter that fisheries, a crucial source of livelihood for the MRB's riparian countries, reaches the highest risk level among other issues. With the average risk level ranked 30th out of 286 international river basins, there is no doubt that the MRB is a hot spot for major river-basin-related problems.

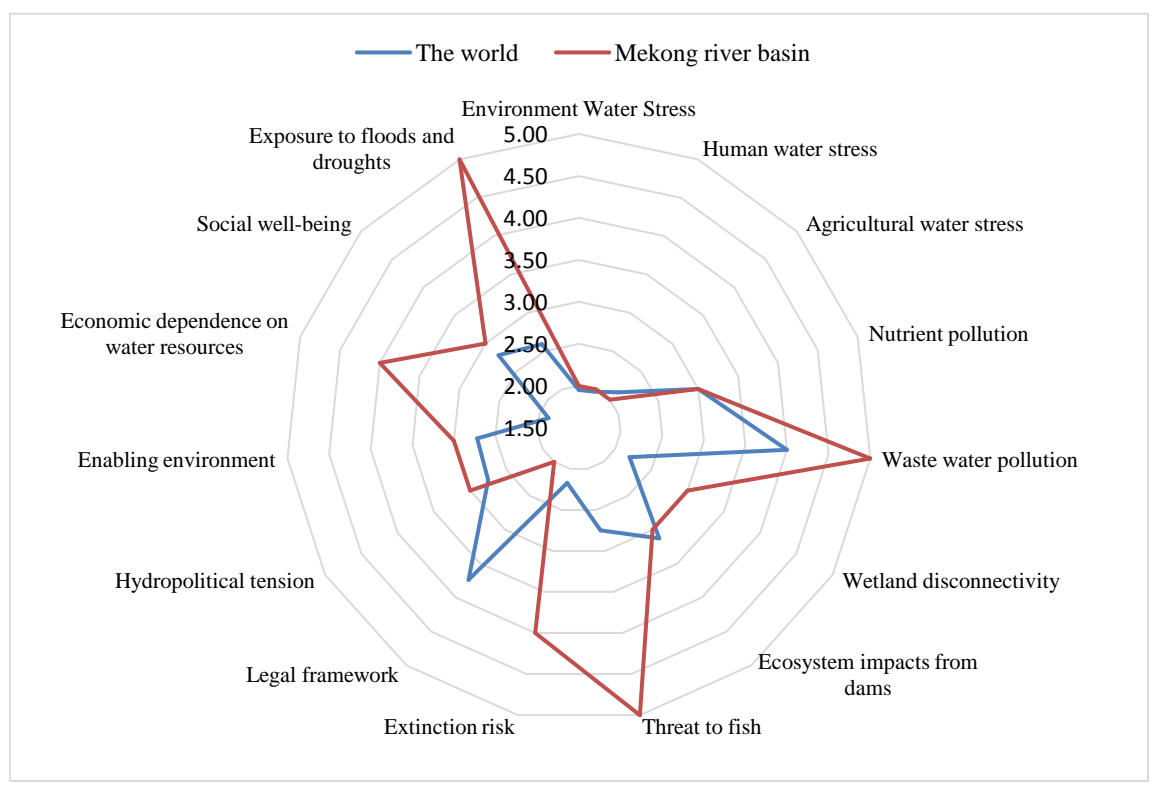

Figure 3. Risk profile comparison between the Mekong river basin and the world (adopted from [50]). 
Risk projections for the future development of global transboundary river basins were made for 2030 and 2050, focusing on four primary sources of water stress. The differences between the projected risks of the MRB and the world are shown in Figure 4. The MRB's expected risk values are lower than those of the global river basins across all criteria except nutrient pollution, the issue with the MRB's highest projected risk value. The growing concern over nutrient balance in the LMB was also addressed in a study by Liljeström et al. (2012), which makes the constructive suggestion that the LMB should take urgent action to control water pollution and improve the basin water quality [54]. Additionally, the risk levels continue to increase over time in both cases, posing severe challenges to the long-term development of river basins around the world and necessitating a massive collaborative effort to solve.

\subsubsection{A Comparison between the LMB Countries}

There are some apparent similarities in the distribution of risks between the four LMB countries (Figure 5). Compared with other issues, wastewater pollution, the threat to fish and exposure to floods and droughts remain at the highest risk levels. In contrast, environmental and agricultural water stress risks stand at the lowest levels for all countries. Concerning the economic dependence on the Mekong water, we are led to the conclusion that the larger the proportion of the basin country' area in the LMB is, the heavier the country depends on the river water resource economically. For example, Laos and Cambodia, two riparian countries covering the two largest MRB portions at $20 \%$ and $27 \%$, respectively, have the highest economic dependence risk points (five points). Interestingly, a noticeable difference in the risks of human water stress can be seen in Laos and Vietnam in relation to their geographical location in the LMB. The most upstream country in the LMB, Laos, has a deficient low-risk level for human-related water use, whereas that of Vietnam, the most downstream country, is relatively high at three risk points.

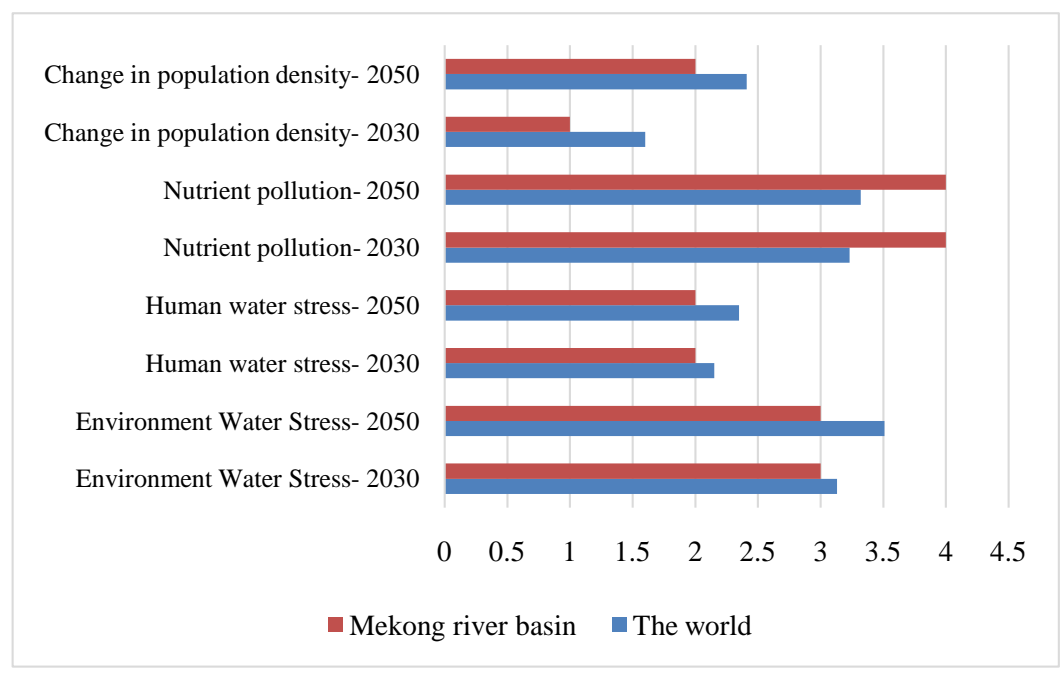

Figure 4. Projections for risk levels of the MRB and the world for 2030 and 2050 (adopted from [50]). 


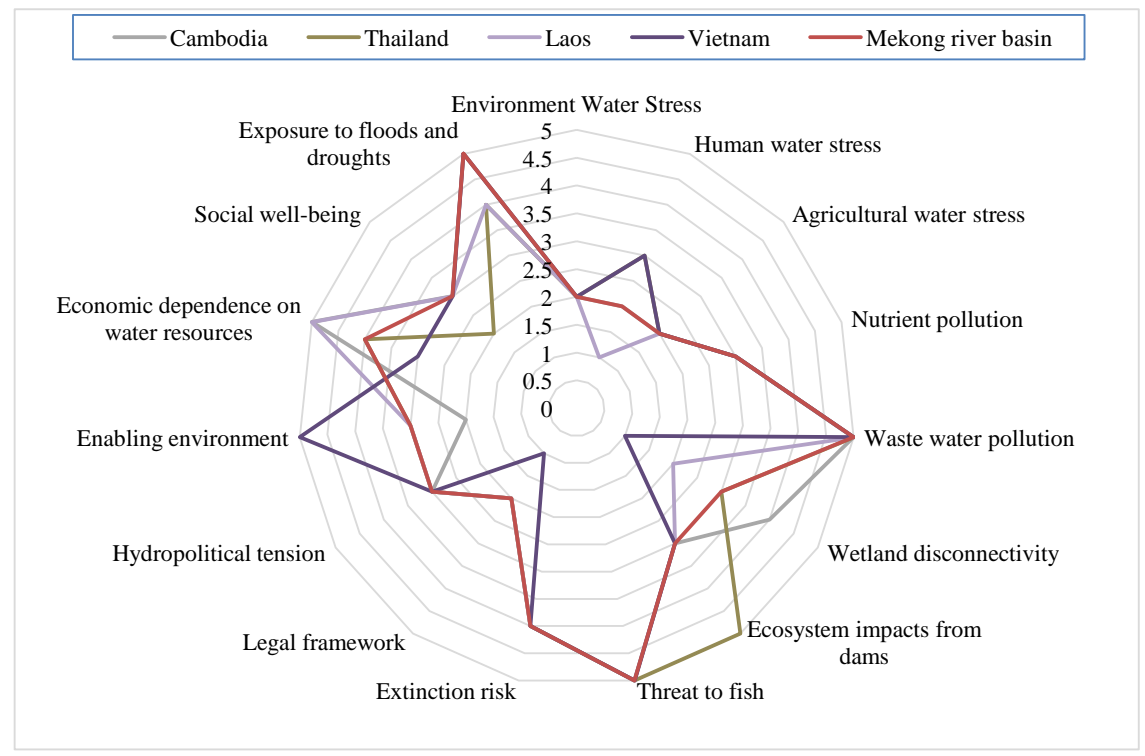

Figure 5. Risk profile comparison among member countries in the LMB (adopted from [50]).

The future trends in the change of risks to human beings and the LMB riparian countries' environment are clearly illustrated in Figure 6. There is no difference in projections of risk over time in Cambodia, Thailand and Vietnam, except for Laos, which experienced an upward trend in risks to environmental water stress. Compared to the current risk levels described in Figure 4, those of Cambodia, Laos, and Vietnam remain unchanged for about forty years. In contrast, Thailand expects to experience a steady increase in the risk points of both human and environmental water stress, with one point higher in each stress category.

\subsection{MCDA Model Analysis for the LMB}

\subsubsection{Criteria Weights}

C1 (water quantity) with a final weight of 0.1463 was the main criterion of the minor importance to the decision-making process in the LMB because it had the lowest risk point while C3 (ecosystem) and C4 (socioeconomics) stood together at the highest positions (Table 5).

The sub-criteria local weights followed by their final weights are described adjacent to their corresponding main criteria to illustrate each sub-criterion relative importance to its main criterion. Of the nine sub-criteria, C3.2 (threat to fish) ranked first, which means that fisheries might be the sector facing the most severe risk over the development of water resources in the LMB. Interestingly, although associated with the third-ranked main criteria, C2.2 (wastewater pollution) with a final weight very close to that of $\mathrm{C} 3.2$ was the second important criterion. In contrast, C4.2 (societal-well-being), the sub-criterion that belongs to the first-ranked main criterion, was the least important criterion. The two other least significant criteria were C1.1 (human water stress) and C1.2 (agricultural water stress). 


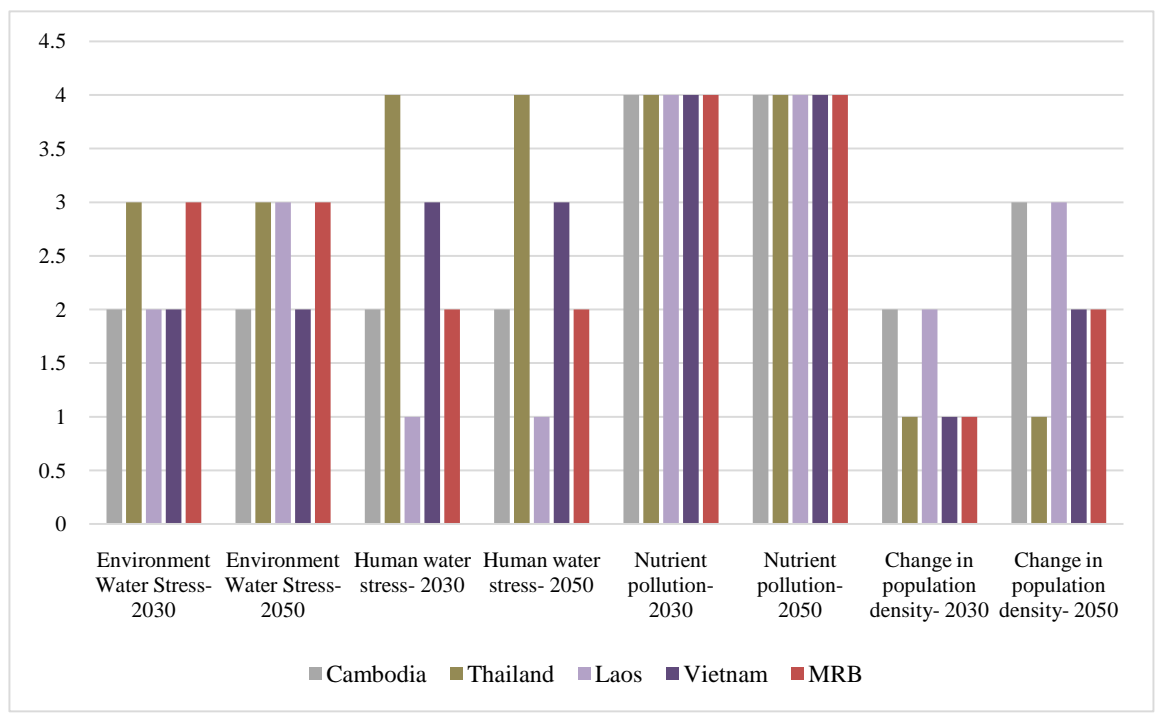

Figure 6. Projections for risk levels of the four member countries of LMB for 2030 and 2050 (adopted from [50]).

Table 5. Results of criteria weights used in the MCDA model.

\begin{tabular}{|c|c|c|c|c|c|c|}
\hline \multicolumn{3}{|c|}{ Main criteria } & \multicolumn{4}{|c|}{ Sub-criteria } \\
\hline & Risk point & Final weight & & Risk point & Local weight & Final weight \\
\hline \multirow[t]{2}{*}{$\mathrm{C} 1$} & 2.00 & 0.1463 & $\mathrm{C} 1.1$ & 2.00 & 0.5000 & 0.0732 \\
\hline & & & $\mathrm{C} 1.2$ & 2.00 & 0.5000 & 0.0732 \\
\hline \multirow[t]{2}{*}{$\mathrm{C} 2$} & 3.67 & 0.2683 & $\mathrm{C} 2.1$ & 3.00 & 0.3750 & 0.1006 \\
\hline & & & $\mathrm{C} 2.2$ & 5.00 & 0.6250 & 0.1677 \\
\hline \multirow[t]{2}{*}{$\mathrm{C} 3$} & 4.00 & 0.2927 & C 3.1 & 3.00 & 0.3750 & 0.1098 \\
\hline & & & C 3.2 & 5.00 & 0.6250 & 0.1829 \\
\hline \multirow[t]{3}{*}{$\mathrm{C} 4$} & 4.00 & 0.2927 & C4.1 & 4.00 & 0.3333 & 0.0976 \\
\hline & & & C4.2 & 3.00 & 0.2500 & 0.0732 \\
\hline & & & C4.3 & 5.00 & 0.4167 & 0.1220 \\
\hline
\end{tabular}

\subsubsection{Final Rankings of the Scenarios}

After determining the criteria weights concerning the MCDA model's goal, the scenarios' prioritisation results against each criterion were calculated and presented in Figure 7 and Figure 8 as examples. As to these two particular criteria ( $\mathrm{C} 1$ and $\mathrm{C} 2)$, in general, the top-ranked water development scenario concerning the potential risks to the environment and ecosystem in the LMB was M1-the baseline scenario, followed by M2 and M3. Nonetheless, there was a noticeable difference of the priority order of three scenarios regarding criterion C2.1 (nutrient pollution): Scenario M2 remained the same ranking, whereas M1 and M3 were placed in reverse order. It can be seen that the ranking of a particular scenario according to one criterion might be higher or lower than that according to the other criteria. 


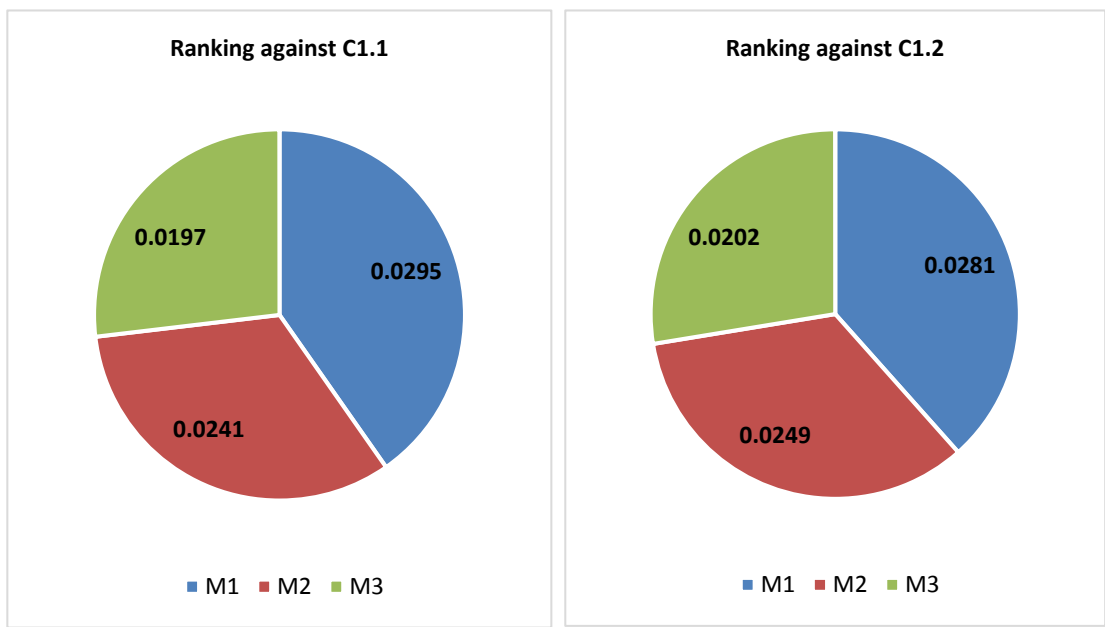

Figure 7. Rankings of three scenarios against C1 (water quantity).

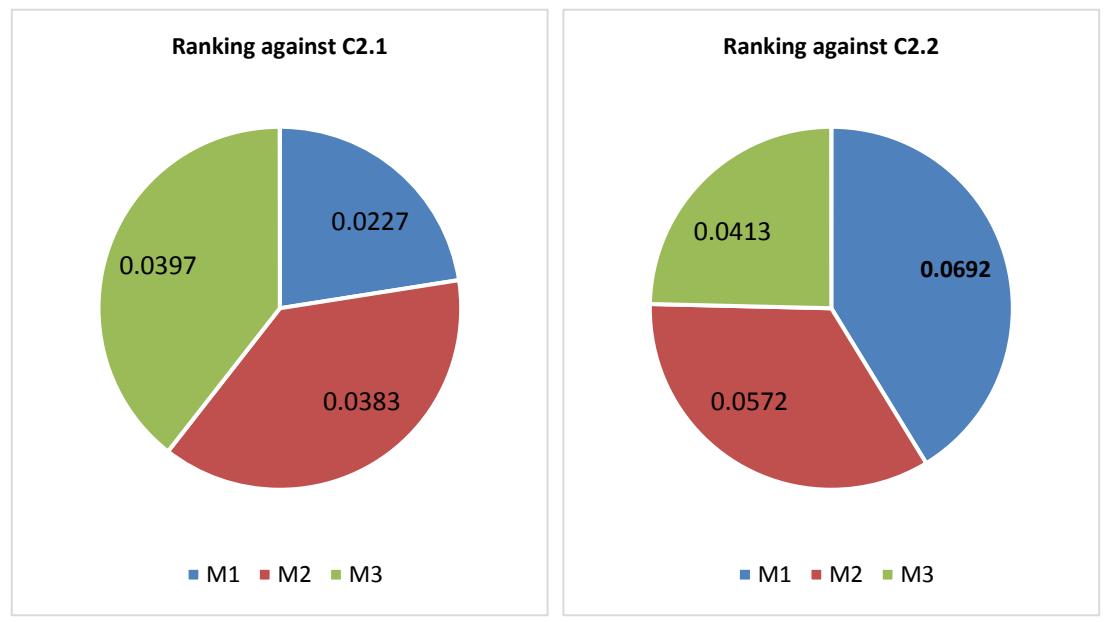

Figure 8. Rankings of three scenarios against C2 (water quality).

The preference levels of each development scenario across all criteria and the results of the final rankings of three main scenarios are summarised in Table 6. The baseline scenario (M1) was the most preferred, the planned development scenario (M3) was the least preferred and the definite future development scenario (M2) stood in the middle. Notably, M1 turned out to be a dominantly favorable scenario as it received a final weight (level of preference) 1.7 times higher than that of the last-ranked scenario (M3) (with the performance score of 0.4244 and 0.2509 , respectively). In the case of taking into account different groups of criteria, there were dramatic changes in the level of preference between the scenarios over each group. For example, if considering only main criteria $\mathrm{C} 1$ as a group of two sub-criteria, C1.1 and C1.2, the level of preference of the first-ranked scenario (M1) was 1.4 times higher than that of the last-ranked scenario (M3) (0.0567 compared to 0.0399 ), while this proportion between M1 and M3 when considering only main criteria C3 was considerably higher at around 3.2 times. 
Table 6. Final rankings of the scenarios in the MCDA model of the LMB.

\begin{tabular}{cccccccccccc}
\hline \multirow{2}{*}{ Scenario } & \multicolumn{2}{c}{ C1 } & \multicolumn{2}{c}{ C2 } & \multicolumn{2}{c}{ C3 } & \multicolumn{2}{c}{ C4 } & Final & Ranking \\
\cline { 2 - 8 } & C1.1 & C1.2 & C2.1 & C2.2 & C3.1 & C3.2 & C4.1 & C4.2 & C4.3 & weight & \\
\hline M1 & 0.0295 & 0.0281 & 0.0227 & 0.0692 & 0.0797 & 0.0829 & 0.0396 & 0.0250 & 0.0479 & 0.4244 & 1 \\
M2 & 0.0241 & 0.0249 & 0.0383 & 0.0572 & 0.0220 & 0.0569 & 0.0323 & 0.0244 & 0.0447 & 0.3247 & 2 \\
M3 & 0.0197 & 0.0202 & 0.0397 & 0.0413 & 0.0081 & 0.0432 & 0.0257 & 0.0237 & 0.0294 & 0.2509 & 3
\end{tabular}

Table 6 indicates significant differences between the three scenarios in comparing each scenario's performance across all criteria. Scenario M1 delivered the best performance on criterion C3.2 (threat to fish) and the worst performance on criterion C2.1 (nutrient pollution) (with the performance score of 0.0829 and 0.0227 , respectively), which means that in scenario M1, the LMB faced the lowest risk in relation to the threat to fish, and at the same time, it had to deal with the highest risk originated from nutrient pollution. Accordingly, the best and the worst performances of scenario M2 were on criteria C2.2 (wastewater pollution) and C3.1 (ecosystem impacts from dams), and those of scenario M3 were on criteria C3.2 (threat to fish) and C3.1, respectively. Note that the impacts of dams on ecosystems (C3.1), which created the significant risk to the water development of the LMB in 2020 (M2), is surprisingly becoming the minor risk to the river basin's future growth.

\subsection{MCDA Model Analysis for the LMB Member Countries}

The four member countries' MCDA models were developed to analyse and rank the water development scenarios in priority order. Similar to the LMB's MCDA model, the basin country model used the same set of the main criteria and their corresponding sub-criteria except those of main criteria C2 because the two sub-criteria of C2 (nutrient pollution and wastewater pollution) are pollutionrelated issues, which cannot be clearly distinguished by country level. Consequently, its two sub-criteria (C2.1 and C2.2) were not incorporated into the basin country model. The results of criteria weights and the priority order of three water development scenarios are described below.

\subsubsection{Criteria Weights}

When considering the relative importance of the main criteria to the decision-making process, $\mathrm{C} 1$ (Water quantity) was the least favorable criterion to all countries. In contrast, the most favorable one was varied slightly but only switching between C3 (ecosystems) and C4 (socioeconomics) (Figure 9).

The global weights of all sub-criteria by countries were illustrated in Figure 10. Four member states highlighted C3.2 (Threat to fish) as the most important issue, which accounted for approximately $20 \%$ of all sub-criteria total weights. Nonetheless, the rankings of other sub-criteria appeared relatively different between riparian countries. In Laos and Thailand, the two upper countries, human water stress (C1.1) and societal wellbeing (C4.2), respectively, represented the 


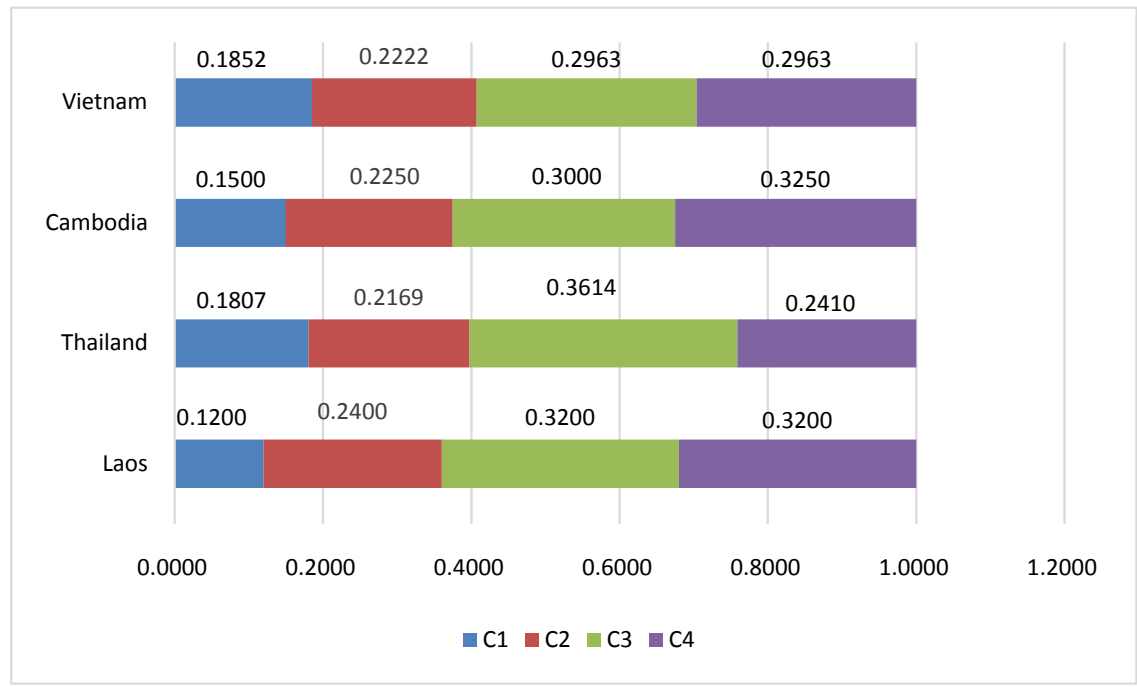

Figure 9. Final weights of the main criteria of the LMB riparian countries.

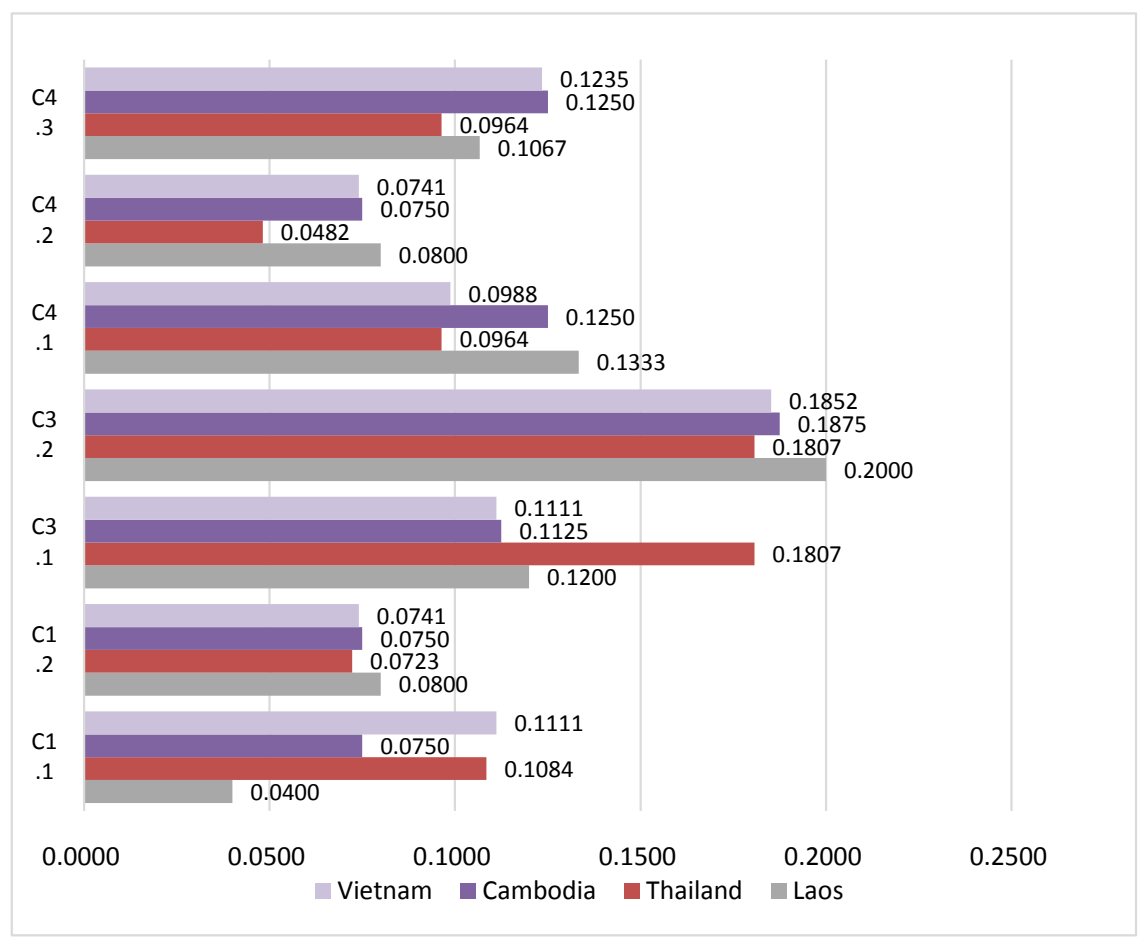

Figure 10. Final weights of sub-criteria of the LMB riparian countries.

criteria with the lowest priority regarding the risk to the LMB development. In contrast, there were three criteria $(\mathrm{C} 1.1, \mathrm{C} 1.2, \mathrm{C} 4.2)$ and two criteria $(\mathrm{C} 1.2, \mathrm{C} 4.2)$ ranked at the last positions in the criteria priority list in Cambodia and Vietnam.

\subsubsection{Final Rankings of the Scenarios}

The overall weights of the criteria and the final ranking of water development scenarios for the four LMB countries are summarised in Tables 7-10. Surprisingly, the preference order of development scenarios were considerably different from country to country and can be categorised into Group 1 (Laos and 
Thailand), and Group 2 (Cambodia and Vietnam). Taking Group 1 into consideration, scenario M1 was identified as the most favorable scenario, followed by M2 and M3, while the final ranking order from the best to the worst of Group 2 was M1, M3 and M2. Although similar to the result of the LMB, M1 was ranked as the best scenario by all countries; M2 and M3 were evaluated diversely between the two upper and the two lower countries. These differences might be explained by the global weights of each country's criteria. For example, in Thailand, M2 was the scenario of higher priority than M3 across most criteria, which resulted in the higher final weight of M2 than that of M3 $(0.3308>$ 0.2906). On the contrary, despite rating $M 2$ equal to or higher than M3 across five out of nine criteria, Vietnam finally ranked M3 higher than M2 when considering all criteria together $(0.3335>0.2920)$.

Table 7. Final rankings of the scenarios of Laos.

\begin{tabular}{|c|c|c|c|c|c|c|c|c|c|c|}
\hline \multirow{2}{*}{ Scenario } & \multicolumn{2}{|c|}{$\mathrm{C} 1$} & \multirow{2}{*}{$\mathrm{C} 2$} & \multicolumn{2}{|c|}{$\mathrm{C} 3$} & \multicolumn{3}{|c|}{$\mathrm{C} 4$} & \multirow{2}{*}{$\begin{array}{c}\text { Final } \\
\text { weight }\end{array}$} & \multirow{2}{*}{ Ranking } \\
\hline & C1.1 & $\mathrm{C} 1.2$ & & C3.1 & C3.2 & C4.1 & C4.2 & $\mathrm{C} 4.3$ & & \\
\hline M1 & 0.0164 & 0.0407 & 0.0661 & 0.1030 & 0.0918 & 0.0676 & 0.0282 & 0.0369 & 0.4508 & 1 \\
\hline M2 & 0.0131 & 0.0262 & 0.0826 & 0.0117 & 0.0617 & 0.0438 & 0.0272 & 0.0344 & 0.3009 & 2 \\
\hline M3 & 0.0104 & 0.0131 & 0.0913 & 0.0053 & 0.0465 & 0.0219 & 0.0246 & 0.0353 & 0.2484 & 3 \\
\hline
\end{tabular}

Table 8. Final rankings of the scenarios of Thailand.

\begin{tabular}{|c|c|c|c|c|c|c|c|c|c|c|}
\hline \multirow{2}{*}{ Scenario } & \multicolumn{2}{|c|}{$\mathrm{C} 1$} & \multirow{2}{*}{$\mathrm{C} 2$} & \multicolumn{2}{|c|}{ C3 } & \multicolumn{3}{|c|}{$\mathrm{C} 4$} & \multirow{2}{*}{$\begin{array}{l}\text { Final } \\
\text { weight }\end{array}$} & \multirow{2}{*}{ Ranking } \\
\hline & $\mathrm{C} 1.1$ & $\mathrm{C} 1.2$ & & C3.1 & C3.2 & C4.1 & $\mathrm{C} 4.2$ & C4.3 & & \\
\hline M1 & 0.0422 & 0.0359 & 0.0651 & 0.0602 & 0.0777 & 0.0479 & 0.0163 & 0.0332 & 0.3786 & 1 \\
\hline M2 & 0.0359 & 0.0213 & 0.0797 & 0.0602 & 0.0598 & 0.0282 & 0.0160 & 0.0298 & 0.3308 & 2 \\
\hline M3 & 0.0303 & 0.0151 & 0.0721 & 0.0602 & 0.0432 & 0.0203 & 0.0159 & 0.0335 & 0.2906 & 3 \\
\hline
\end{tabular}

Table 9. Final rankings of the scenarios of Cambodia.

\begin{tabular}{|c|c|c|c|c|c|c|c|c|c|c|}
\hline \multirow{2}{*}{ Scenario } & \multicolumn{2}{|c|}{$\mathrm{C} 1$} & \multirow{2}{*}{$\mathrm{C} 2$} & \multicolumn{2}{|c|}{$\mathrm{C} 3$} & \multicolumn{3}{|c|}{$\mathrm{C} 4$} & \multirow{2}{*}{$\begin{array}{c}\text { Final } \\
\text { weight }\end{array}$} & \multirow{2}{*}{ Ranking } \\
\hline & C1.1 & C1.2 & & C3.1 & C3.2 & C4.1 & C4.2 & C4.3 & & \\
\hline M1 & 0.0313 & 0.0353 & 0.0433 & 0.0000 & 0.0830 & 0.0628 & 0.0255 & 0.0369 & 0.3180 & 1 \\
\hline M2 & 0.0244 & 0.0258 & 0.0691 & 0.0000 & 0.0593 & 0.0379 & 0.0248 & 0.0359 & 0.2772 & 3 \\
\hline M3 & 0.0193 & 0.0139 & 0.1126 & 0.0000 & 0.0453 & 0.0243 & 0.0247 & 0.0522 & 0.2923 & 2 \\
\hline
\end{tabular}

Table 10. Final rankings of the scenarios of Vietnam.

\begin{tabular}{|c|c|c|c|c|c|c|c|c|c|c|}
\hline \multirow{2}{*}{ Scenario } & \multicolumn{2}{|c|}{$\mathrm{C} 1$} & \multirow{2}{*}{$\mathrm{C} 2$} & \multicolumn{2}{|c|}{$\mathrm{C} 3$} & \multicolumn{3}{|c|}{$\mathrm{C} 4$} & \multirow{2}{*}{$\begin{array}{c}\text { Final } \\
\text { weight }\end{array}$} & \multirow{2}{*}{ Ranking } \\
\hline & C1.1 & C1.2 & & C3.1 & C3.2 & C4.1 & C4.2 & C4.3 & & \\
\hline M1 & 0.0450 & 0.0243 & 0.0478 & 0.0675 & 0.0850 & 0.0323 & 0.0248 & 0.0478 & 0.3745 & 1 \\
\hline M2 & 0.0364 & 0.0249 & 0.0655 & 0.0225 & 0.0566 & 0.0330 & 0.0246 & 0.0285 & 0.2920 & 3 \\
\hline M3 & 0.0298 & 0.0249 & 0.1089 & 0.0211 & 0.0436 & 0.0335 & 0.0246 & 0.0472 & 0.3335 & 2 \\
\hline
\end{tabular}




\section{Discussion}

As previous sections revealed, the risks concerning water-related issues, ecosystem, environment and human beings are relatively different between the MRB and the basins worldwide, particularly in terms of the threat to fish, exposure to flood and drought and economic dependence on water resources. The findings highlight the risk originated from the threat to fish, which poses a more significant danger to the LMB's future development than the other river basins. This issue was also addressed by MRC (2019) that the growing pressures on fisheries negatively impacts on the environmental condition of the LMB, and immediate actions are needed to manage fisheries better [9]. The high level of risk in fisheries might be explained by the four riparian countries' large fisheries production. According to MRC (2019), all member countries' fisheries production in the river basin accounted for $45 \%$ of their total national fisheries production in 2015, equivalent to approximately 17 billion US dollars [9].

In addition, the risk of floods and droughts in the LMB was noticeably higher than that at the global scale and recognised as a prominent source of risk to the LMB development. Compared with other river basins, strong evidence indicated that severe floods and droughts resulting from climate change substantially threatened the LMB, making it the region of high vulnerability to climate change [55]. These negative impacts can be resolved by improving the LMB flood and drought forecast and further cooperation with China, the most upper country in MRB. The renewal agreement signed by MRC and China's data sharing in July 2019 can pave the way for effective flood and drought management to reduce the damages to the basin's environment and livelihoods.

The fact that the LMB have higher economic dependence on water resources than the average level of river basins worldwide could result from the large shares in the total basin population of the four riparian countries. As estimated in 2015, more than one-third of approximately 65 million people living in the LMB come from Thailand and Vietnam, while the Cambodian accounts for one fifth and Laos take the rest of the LMB population [9]. This leads to the heavy dependence on the Mekong River water resources for food and livelihoods. Similarly, the economic reliance on river water is also greatly influenced by each country's share in the basin population.

Relating to the projected risk levels, the estimated values of nutrient pollution risk of the LMB were noticeably higher than those of the global average level. These findings are consistent with a previous study of Maavara et al. (2015) that expressed severe concern about the increase in the projected Phosphorous concentration in dam reservoirs in major transboundary river basins like Mekong and Amazon that would expand surface water eutrophication [56].

Concerning the LMB's water scenarios evaluation, two upper countries (Laos and Thailand) had the same results as the LMB, while Cambodia and Vietnam's assessment results appeared slightly different. The findings show a common trend to both the basin and all riparian countries towards the ranking of M1, the 
highest priority scenario in terms of risk to ecosystem, environment and human beings of the LMB. Considering expected changes in the LMB, the study results also reveal that the future water development scenarios of the LMB posed continuous threats to member countries and the LMB over time. There are some possible explanations for the final evaluation results relating to population increase, climate change, and the expansion of proposed hydropower dams both in Mekong mainstream and tributaries. First, a high projected population density, as described in this study, along with the total expected population of 83 million people by 2060 [57], is likely to put enormous pressures on the environment and water resources of the LMB. The inappropriate and extensive use of the river water to meet the high demand for drinking, agricultural and industrial water of the growing population leaves the region's environment and ecosystem to degenerate or be destroyed gradually. Secondly, as recognised by MRC (2018), climate change continues to happen more widely and seriously in the LMB, has potential negative impacts on livelihoods in the LMB and puts many local communities at the highest vulnerability level in the future [58]. Finally, the rapid development of dam projects by riparian countries would cause massive changes to the fisheries habitats and fish migration patterns, alter the river flow and reduce the ecosystem richness. MRC may take into account the water-related issues with high potential risks, such as the threat to fish, economic dependence on basin water resources or damages of floods and droughts, as well as the trade-offs between economic benefits and the harms to the environment and ecosystem of the basin when making decisions on water-related policy.

This study presents some useful findings for researches on water resource management in the LMB. The results of water scenario evaluation are much dependent on the number and the nature of the criteria included in the MCDA model. To further understand the LMB water development assessment, the policymakers should incorporate all TWAP indicators and climate change impacts into the evaluation model. Also, climate change-related scenarios should be analysed and accessed to obtain extensive effects on the future development of the LMB.

\section{Conclusions}

MRC implemented the Council Study to assess the progress of water-related sectors of the LMB over time and to explore the aggregate impacts of these changes to the sustainable development of the LMB in different scenarios, keeping the focus on environmental, social and economic aspects. By utilizing the MCDA model, this study provides insights into the impacts of the increasing risks to the ecosystem and human beings on the water development of the basin over time, which assists to change the awareness and the perspective toward humans' risks and transboundary river ecosystem of decision-makers. Findings indicate that the MRB, with much higher risk levels than the global average levels in terms of threat to fish, exposure of floods and droughts, and economic 
dependence on water resources, is recognised as the hot spot of river basins at risk. The results of the MCDA model analysis reveal that the baseline scenario M1 was the most preferred scenario posing the lowest threat to the environment and ecosystem while the future development scenarios M2 and M3 brought higher risks to basin over time.

In conclusion, the results suggest several important implications for future practice. Firstly, the MRC and other stakeholders in the LMB should give more concern to high risk-level issues such as the threat to fish or damages of floods and droughts during the post-event evaluation and in the early stage of basin planning at both local and river basin level. It would be valuable to consider the trade-offs among monetary benefits, the degradation of the environment and ecosystem, and the harm to human beings in the long-term for the better sustainable development of the LMB. Secondly, the benefit-sharing mechanism in the LMB, which mainly focused on ensuring the equitable distribution of benefits derived from utilising basin water resources, should be revised more effectively by taking the potential risks to each country in the long-term as constraints. Therefore, the member states have another incentive to establish a complete benefit-sharing scheme covering the river basin development aspects. In the future, a significant challenge facing MRC will be to improve its policy measures and adequately invest in appropriate infrastructure to mitigate the negative impacts of high-risk issues.

\section{Acknowledgements}

I would like to sincerely thank Professor Makoto Usami from Kyoto University for his guidance, support and valuable advices and my lab mates for their feedbacks. I also thank Mr. Nguyen Huy Phuong from Vietnam National Mekong Committee and Mr. Nguyen Tuan Quang from Ministry of Natural Resources and Environment of Vietnam for providing data for the research. This study was supported by the Ministry of Education, Culture, Sports, Science and Technology of Japan through Monbukagakusho Scholarship.

\section{Conflicts of Interest}

The authors declare no conflicts of interest regarding the publication of this paper.

\section{References}

[1] Wolf, A.T., Kramer, A., Carius, A. and Dabelko, G.D. (2005) Managing Water Conflict and Cooperation. State World 2005 Redefining Glob. Secur., 80-95.

[2] UN-Water (2015) Good Practices in Transboundary Water Cooperation. https://www.unwater.org/water-facts/transboundary-waters/

[3] Glennie, P., Bertule, M., Eynard, J., Jaiteh, M., Schneider, C. and Bjørnsen, P. (2016) Chapter 1: Introduction. In UNEP-DHI and UNEP (2016). In: Transboundary River Basins: Status and Trends, United Nations Environment Programme, Nairobi, $1-7$. 
[4] WWAP (2012) The United Nations World Water Development Report 4: Managing Water under Uncertainty and Risk. https://unesdoc.unesco.org/ark:/48223/pf0000215644

[5] Zeitoun, M., Goulden, M. and Tickner, D. (2013) Current and Future Challenges Facing Transboundary River Basin Management. WIREs Climate Change, 4, 331-349. https://doi.org/10.1002/wcc.228

[6] UN-Water (2009) Water in a Changing World. https://unesdoc.unesco.org/ark:/48223/pf0000181993

[7] UN-Water (2006) Water: A Shared Responsibility; the United Nations World Water Development Report 2, Executive Summary. https://unesdoc.unesco.org/ark:/48223/pf0000144409

[8] Sanchez, J.C. and Roberts, J. (2014) Transboundary Water Governance: Adaptation to Climate Change. IUCN, Gland.

[9] MRC (2019) State of the Basin Report 2018. Mekong River Comm., 1-226.

[10] Chea, R., Grenouillet, G. and Lek, S. (2016) Evidence of Water Quality Degradation in Lower Mekong Basin Revealed by Self-Organizing Map. PLoS One, 11, e0145527. https://doi.org/10.1371/journal.pone.0145527

[11] MRC (2017) Mekong Climate Change Adaptation Strategy and Action Plan. Mekong River Commission, Vientiane.

[12] MRC (2011) Planing Altas of the Lower Mekong River Basin. Mekong River Commission, Vientiane.

[13] MRC (2010) State of the Basin Report 2010. Mekong River Commission, Vientiane.

[14] MRC (2003) State of the Basin Report 2003 Executive Summary. Mekong River Commission, Vientiane.

[15] MRC (2011) Basin Development Plan Programme 2: Assessment of Basin-wide Development Scenarios. Mekong River Commission, Vientiane.

[16] MRC (2017) The Council Study: The Study on Sustainable Management and Development of the Mekong River Basin, including Impacts of Mainstream Hydropower Projects. Thematic Report on the Positive and Negative Impacts of Hydropower Development on the Social, Environment. MRC, Mekong River Commission, p. 107.

[17] ICEM (2010) MRC Strategic Environmental Assessment (SEA) of Hydropower on the Mekong Mainstream. ICEM, Hanoi.

[18] Sandoval-Solis, S., Teasley, R.L., McKinney, D.C., Thomas, G.A. and Patiño-Gomez, C. (2013) Collaborative Modeling to Evaluate Water Management Scenarios in the Rio Grande Basin. JAWRA Journal of the American Water Resources Association, 49, 639-653. https://doi.org/10.1111/jawr.12070

[19] Petersen-Perlman, J., De Stefano, L., Petersen-Perlman, J.D., Sproles, E.A., Eynard, J. and Wolf, A.T. (2017) Assessment of Transboundary River Basins for Potential Hydro-Political Tensions. Global Environmental Change, 45, 35-46. https://doi.org/10.1016/j.gloenvcha.2017.04.008

[20] Ma, J., Hipel, K.W., De, M. and Cai, J. (2008) Transboundary Water Policies: Assessment, Comparison and Enhancement. Water Resources Management, 22, 1069-1087. https://doi.org/10.1007/s11269-007-9211-y

[21] Sarband, E.M., Araghinejad, S. and Attari, J. (2020) Developing an Interactive Spatial Multi-Attribute Decision Support System for Assessing Water Resources Allocation Scenarios. Water Resources Management, 34, 447-462. https://doi.org/10.1007/s11269-019-02291-y 
[22] Safavi, H.R., Golmohammadi, M.H. and Sandoval-Solis, S. (2016) Scenario Analysis for Integrated Water Resources Planning and Management under Uncertainty in the Zayandehrud River Basin. Journal of Hydrology, 539, 625-639. https://doi.org/10.1016/j.jhydrol.2016.05.073

[23] Li, X. (2012) Hydropower in the Mekong River Basin: A Balancing Test. Environmental Claims Journal, 24, 51-69. https://doi.org/10.1080/10406026.2012.663299

[24] Piman, T., Cochrane, T.A., Arias, M.E., Dat, N.D. and Vonnarart, O. (2015) Managing Hydropower under Climate Change in the Mekong Tributaries. In: Shrestha, S., Anal, A., Salam, P. and van der Valk, M., Eds., Managing Water Resources under Climate Uncertainty, Springer, Cham, 223-248.

https://doi.org/10.1007/978-3-319-10467-6_11

[25] Kuenzer, C., Campbell, I., Roch, M., Leinenkugel, P., Tuan, V.Q. and Dech, S. (2013) Understanding the Impact of Hydropower Developments in the Context of Upstream-Downstream Relations in the Mekong River Basin. Sustainability Science, 8, 565-584. https://doi.org/10.1007/s11625-012-0195-Z

[26] Kummu, M., Koponen, J. and Sarkkula, J. (2005) Assessing Impacts of the Mekong Development in the Tonle Sap Lake. In: Proceedings of the International Symposium on Role of Water Sciences in Transboundary River Basin Management, Regional Network Office for Urban Safety, School of Civil Engineering, Asian Institute of Technology, Thailand, 10-12.

[27] Intralawan, A., Wood, D., Frankel, R., Costanza, R. and Kubiszewski, I. (2018) Tradeoff Analysis between Electricity Generation and Ecosystem Services in the Lower Mekong Basin. Ecosystem Services, 30, 27-35.

https://doi.org/10.1016/j.ecoser.2018.01.007

[28] Piman, T., Lennaerts, T. and Southalack, P. (2013) Assessment of Hydrological Changes in the Lower Mekong Basin from Basin-Wide Development Scenarios. Hydrological Processes, 27, 2115-2125. https://doi.org/10.1002/hyp.9764

[29] Grigg, N.S. (2015) Problem Archetypes as Common Ground for Water Resources Management Education. Water Resources Management, 29, 3535-3550. https://doi.org/10.1007/s11269-015-1013-Z

[30] Yilmaz, B. and Harmancioglu, N.B. (2010) Multi-Criteria Decision Making for Water Resource Management: A Case Study of the Gediz River Basin, Turkey. Water $S A$, 36, 563-576. https://doi.org/10.4314/wsa.v36i5.61990

[31] Tzeng, G.-H. and Huang, J.-J. (2011) Multiple Attribute Decision Making: Methods and Applications. CRC Press, New York. https://doi.org/10.1201/b11032

[32] Velasquez, M. and Hester, P.T. (2013) An Analysis of Multi-Criteria Decision Making Methods. International Journal of Operational Research, 10, 56-66.

[33] Zolghadr-Asli, B., Bozorg-Haddad, O., Enayati, M. and Chu, X. (2021) A Review of 20-Year Applications of Multi-Attribute Decision-Making in Environmental and Water Resources Planning and Management. Environment, Development and Sustainability, 1-26. https://doi.org/10.1007/s10668-021-01278-3

[34] Çelen, A. (2014) Comparative Analysis of Normalization Procedures in TOPSIS Method: With an Application to Turkish Deposit Banking Market. Informatica, 25, 185-208. https://doi.org/10.15388/Informatica.2014.10

[35] Fallah-Mehdipour, E., Bozorg-Haddad, O. and Loáiciga, H.A. (2018) Calculation of Multi-Objective Optimal Tradeoffs between Environmental Flows and Hydropower Generation. Environmental Earth Sciences, 77, Article No. 453.

https://doi.org/10.1007/s12665-018-7645-6

[36] Mani, M., Bozorg-Haddad, O. and Loáiciga, H.A. (2019) A New Framework for the 
Optimal Management of Urban Runoff with Low-Impact Development Stormwater Control Measures Considering Service-Performance Reduction. Journal of Hydroinformatics, 21, 727-744. https://doi.org/10.2166/hydro.2019.126

[37] He, L., Shao, F. and Ren, L. (2020) Identifying Optimal Groundwater Remediation Strategies through a Simulation-Based PROMETHEE-TOPSIS Approach: An Application to a Naphthalene-Contaminated Site. Human and Ecological Risk Assessment, 26, 1550-1568. https://doi.org/10.1080/10807039.2019.1591267

[38] Pietersen, K. (2006) Multiple Criteria Decision Analysis (MCDA): A Tool to Support Sustainable Management of Groundwater Resources in South Africa. Water $S A, 32,119-128$. https://doi.org/10.4314/wsa.v32i2.5242

[39] Barzegar, R., Moghaddam, A.A., Adamowski, J. and Nazemi, A.H. (2019) Delimitation of Groundwater Zones under Contamination Risk Using a Bagged Ensemble of Optimized DRASTIC Frameworks. Environmental Science and Pollution Research, 26, 8325-8339. https://doi.org/10.1007/s11356-019-04252-9

[40] Srdjevic, B., Medeiros, Y.D.P. and Faria, A.S. (2004) An Objective Multi-Criteria Evaluation of Water Management Scenarios. Water Resources Management, 18, 35-54. https://doi.org/10.1023/B:WARM.0000015348.88832.52

[41] Goodwin, D., Raffin, M., Jeffrey, P. and Smith, H.M. (2019) Stakeholder Evaluations of Risk Interventions for Non-Potable Recycled Water Schemes: A Case Study. Science of the Total Environment, 674, 439-450. https://doi.org/10.1016/j.scitotenv.2019.04.044

[42] Qin, X.-S., Huang, G.H., Chakma, A., Nie, X.H. and Lin, Q.G. (2008) A MCDM-Based Expert System for Climate-Change Impact Assessment and Adaptation Planning-A Case Study for the Georgia Basin, Canada. Expert Systems with Applications, 34, 2164-2179. https://doi.org/10.1016/j.eswa.2007.02.024

[43] Vila, M., Afsordegan, A., Agell, N., Sánchez, M. and Costa, G. (2018) Influential Factors in Water Planning for Sustainable Tourism Destinations. Journal of Sustainable Tourism, 26, 1241-1256. https://doi.org/10.1080/09669582.2018.1433183

[44] Marques, J., Cunha, M. and Savić, D. (2017) Ranking Alternatives for the Flexible Phased Design of Water Distribution Networks. Procedia Engineering, 186, 567-575. https://doi.org/10.1016/j.proeng.2017.03.271

[45] Cunha, M., Marques, J., Creaco, E. and Savić, D. (2019) A Dynamic Adaptive Approach for Water Distribution Network Design. Journal of Water Resources Planning and Management, 145, 4019026. https://doi.org/10.1061/(ASCE)WR.1943-5452.0001085

[46] Irvem, A. and Topaloğlu, F. (2012) Identification of Flood Risk Area in the Orontes River Basin, Turkey, Using Multi-Criteria Decision Analyses. Journal of Food, Agriculture and Environment, 10, 895-899.

[47] Lee, M., Yu, C.-Y., Chiang, P.-C. and Hou, C.-H. (2018) Water-Energy Nexus for Multi-Criteria Decision Making in Water Resource Management: A Case Study of Choshui River Basin in Taiwan. Water (Switzerland), 10, 1740.

https://doi.org/10.3390/w10121740

[48] Taha, R., Dietrich, J., Dehnhardt, A. and Hirschfeld, J. (2019) Scaling Effects in Spatial Multi-Criteria Decision Aggregation in Integrated River Basin Management. Water, 11, 355. https://doi.org/10.3390/w11020355

[49] Qin, J., Fu, X., Peng, S., Xu, Y., Huang, J. and Huang, S. (2019) Asymmetric Bargaining Model for Water Resource Allocation over Transboundary Rivers. International Journal of Environmental Research and Public Health, 16, 1733. https://doi.org/10.3390/ijerph16101733 
[50] UNEP-DHI and UNEP (2016) Transboundary River Basins: Status and Trends. United Nations Environ. Program. (UNEP), Nairobi, Vol. 3.

[51] Macharis, C., Verbeke, A. and De Brucker, K. (2004) The Strategic Evaluation of New Technologies through Multicriteria Analysis: The Advisors Case. Research in Transportation Economics, 8, 443-462. https://doi.org/10.1016/S0739-8859(04)08019-9

[52] Toloie-Eshlaghy, A. and Homayonfar, M. (2011) MCDM Methodologies and Applications: A Literature Review from 1999 to 2009. Research Journal of International Studies, 21, 86-137.

[53] Wątróbski, J., Jankowski, J., Ziemba, P., Karczmarczyk, A. and Zioło, M. (2019) Generalised Framework for Multi-Criteria Method Selection. Omega, 86, 107-124. https://doi.org/10.1016/j.omega.2018.07.004

[54] Liljeström, I., Kummu, M. and Varis, O. (2012) Nutrient Balance Assessment in the Mekong Basin: Nitrogen and Phosphorus Dynamics in a Catchment Scale. International Journal of Water Resources Development, 28, 373-391. https://doi.org/10.1080/07900627.2012.668649

[55] MRC (2020) Annual Report 2019. Mekong River Commission, Vientiane, Vol. 5, No. 1, pp. i-v.

[56] Maavara, T., Parsons, C.T., Ridenour, C., et al. (2015) Global Phosphorus Retention by River Damming. Proceedings of the National Academy of Sciences of the United States Of America, 112, 15603-15608. https://doi.org/10.1073/pnas.1511797112

[57] MRC (2016) Basin Development Strategy 2016-2020. Mekong River Commision.,.

[58] MRC (2018) MRC Council Study: The Study on the Sustainable Management and Development of the Mekong River Basin, Including Impacts of Mainstream Hydropower Projects Coastal Modelling Report. No. January, p. 37.

\section{Supplement Material}

\section{Appendix A. List of Abbreviations}

\begin{tabular}{cc}
\hline BDP & Basin Development Plan \\
BDS & Basin Development Strategy \\
MCDA & Multi-criteria Decision Analysis \\
MRB & Mekong river basin \\
MRC & Mekong River Commission \\
LMB & Lower Mekong Basin \\
TWAP & Transboundary Water Assessment Program \\
UNEP & United Nations Environment Program \\
US EPA & United State Environmental Protection Agency \\
\hline
\end{tabular}

